\title{
The scientific impact of microbial cell factories
}

\author{
Maurilio De Felice ${ }^{1}$, Diethard Mattanovich², Maria Papagianni³, \\ Grzegorz Wegrzyn ${ }^{4}$ and Antonio Villaverde*5,6,7
}

\begin{abstract}
Address: ${ }^{1}$ Department of Structural and Functional Biology, University of Naples Federico II, via Cinthia, 80126 Naples, Italy, ${ }^{2}$ University of Natural Resources and Applied Life Sciences Vienna, Department of Biotechnology, Vienna, Austria, ${ }^{3}$ Department of Hygiene and Technology of Food of Animal Origin, School of Veterinary Medicine, Aristotle University of Thessaloniki, Thessaloniki 54006, Greece, ${ }^{4}$ Department of Molecular Biology, University of Gdansk, Gdansk, Poland, ${ }^{5}$ Institute for Biotechnology and Biomedicine, Autonomous University of Barcelona, Barcelona, Spain, ${ }^{6}$ Department of Genetics and Microbiology, Autonomous University of Barcelona, Barcelona, Spain and ${ }^{7}$ CIBER de Bioingeniería, Biomateriales y Nanomedicina (CIBER-BBN), Bellaterra, 08193 Barcelona, Spain
\end{abstract}

Email: Maurilio De Felice - defelice@unina.it; Diethard Mattanovich - diethard.mattanovich@boku.ac.at; Maria Papagianni - mp2000@vet.auth.gr; Grzegorz Wegrzyn - wegrzyn@biotech.ug.gda.pl; Antonio Villaverde* - avillaverde@servet.uab.es

* Corresponding author

Published: I December 2008

Microbial Cell Factories 2008, 7:33 doi:10.1 186/1475-2859-7-33
Received: 24 November 2008

Accepted: I December 2008

This article is available from: http://www.microbialcellfactories.com/content/7/1/33

(c) 2008 De Felice et al; licensee BioMed Central Ltd.

This is an Open Access article distributed under the terms of the Creative Commons Attribution License (http://creativecommons.org/licenses/by/2.0), which permits unrestricted use, distribution, and reproduction in any medium, provided the original work is properly cited.

\section{Editorial}

Microbial Cell Factories was launched in 2002 under an Open Access policy, to cover a gap in the current offer of the scientific literature in Biotechnology and Applied Microbiology areas. The microbial cell factory concept, although present as a side topic within the scope of many journals in the field, deserves a specific attention as a particular, well defined issue in the microbial production and transformation of biotechnologically relevant substances. Intriguingly, the Cell Factory concept stresses the relevance of host cell genetics and metabolism in the context of the production process, and focus on the physiological aspects of the productive event. Since 2002, the journal has published more than 170 relevant manuscripts in form of Research articles, Technical notes, Reviews and Commentaries, highlighting the role of the hosting cell from both biological and technological sides. The diversity of microbial cell types being incorporated as cell factories (namely bacteria, archae, yeast and filamentous fungi), the methodological adaptation of productive processes (through new genetic engineering tools, microreactors, metagenomic approaches etc) and the diversity of fields in which cell factories become critical (structural biology, food microbiology, natural products, biominery, nanotechnology and biosensing among others), has dramatically expanded the scope covered by Microbial Cell Factories.
The journal has published excellent contributions in those areas, many of them highly cited, and it has been extremely well received by the scientific community becoming now a reference in the current microbial biotechnology literature. Thomson Reuters (ISI) has just released the first official impact factor for Microbial Cell Factories, an impressive 3.36 (for 2007), placing the journal in position 31 (out of 138 listed journals) of the Biotechnology and Applied Microbiology subject. The readers should note that in June's edition of the Journal Citation Reports (JCR) the impact factor of Microbial Cell Factories was erroneously reflected due to a failure in the system aggregating citations. The fault has been corrected in November's edition (on November 20), so the readers and potential authors should now update their records.

The journal has published relevant contributions in specific fields, some of them offering new scientific concepts or summarizing the current state-of-the-art in key methodologies and technical approaches. Regarding protein production, a special attention has been paid to recombinant protein folding and misfolding, especially in conventional hosts such as E. coli. In this regard, the nature, formation and physiological processing of inclusion bodies $[1,2]$, in vitro protein refolding [3], the mechanics of bacterial quality control system [4] and the general conformational stress responses under a host comparative overview [5] have been discussed. Also, the mechanics of 
in vivo protein disaggregation has been extensively revised [6] and the scientific and technical implications of protein folding evaluated, conceptually $[7,8]$ and methodologically [9-11].

Also, several authors have described the successful production of antibodies and other proteins of biotechnological interest in Bacillus megaterium and related species $[12,13]$, while Zweers and coauthors have recently reviewed the use and properties of $B$. subtilis and other species as cell factory for protein production of complex proteins [14], stressing the value of this gram-positive genera as cell factory. Other hosts such as fungi $[15,16]$, lactobacilli and lactococci [17-19] and yeasts [20] have been also revised through different examples and under diverse perspectives. Finally, novel hosts such as coldadapted bacteria [21] or hyperthermoacidophilic archae [22] and their implementation for protein production have been evaluated. From the methodological point of view, purification, analysis of protein aggregation $[23,24]$ and other aspects of protein production and purification have been considered $[25,26]$, while the novelty and biotechnological interests of novel products such as the spider silk proteins [27] have been stressed.

Since the launch, Microbial Cell Factories has focussed strongly on metabolic engineering. Following the process chain, substrate utilization, and the availability of new substrates appears as the first essential topics. Improved utilization of already established substrates like glucose (reviewed in [28]) or sucrose [29] was highlighted. Utilization of the lignocellulose monomer xylose, was a topic of great interest over the last years [30-33]. Following the process chain, metabolic engineering towards the production of bioorganic molecules has been highlighted towards organic acids [34], amino acids [35], secondary metabolites [36,37] and biopolymers [38].

To establish engineered production strains, screening and analysis tools need to be applied. Mattanovich and Borth [39] reviewed single cell sorting applied to biotechnology. Analysis of transcript regulation by DNA microarrays and alternative techniques were applied to protein producing microorganisms [40], as well as amino acid [41] and antibiotics production [42]. Applications and pitfalls of transcriptomics was also reviewed [43]. Proteomics - the differential abundance of cellular proteins in different conditions - was reviewed comprehensively by Graham et al. [44]. While metabolomics methods have been established in the last decade, their application to microbial cell factories are presently upcoming [45]. Applications towards ethanol and biomass [46] and amino acids [47] were described, while sampling, as a critical topic has been recently highlighted [48]. Systems biology as the framework over all these global analytical approaches has been summarized in an editorial in 2007 [49].

Process modelling and design enable the transfer of cell factories towards production processes. Efficient substrate utilization is the first prerequisite for an efficient process [50]. While Cos et al. comprehensively reviewed process operation, monitoring and control for recombinant yeasts [51], modelling has been applied to optimize fed batch processes [52]. Advanced monitoring [53] will enable novel approaches for process optimization and control, while miniaturization of bioreactors [54] bears the chance of a wide expansion of experimental screening and design.

Many important reports published in the journal concerned molecular biology and genetics, including development of biosensors. In the field of analysis and modification of nucleic acids, improved methods for quantitative analysis of yeast RNAs [55], monitoring of gene expression in Pichia pastoris [40], determination of plasmid copy number [56] and generation of site-directed point mutations in Escherichia coli chromosome [57] were developed. Genomic and metabolomic procedures became more and more important in molecular biology and biotechnology. Topics concerning genomics of as diverse organisms as humans [58] and Propionibacterium freudenreichii [59] were addressed. Moreover, effects of the presence of plasmid DNA on metabolism of $E$. coli were reported [60].

Several excellent papers published in the journal concerned microbial gene expression. These include reports on regulation of expression of heat shock genes [2] and the desA gene [61]. A group of very interesting reports may be of high practical importance in the biotechnological use of microbial cell factories. Namely, it was shown that decreased recombinant gene expression from T7 promoters may be due to impaired production of active T7 RNA polymerase in the expression system [62], and that a transient increase of ATP level occurs in response to a temperature up-shift in E. coli [63]. Moreover, several new cloning vectors and expression systems were developed and described (see, for example references [11,64-67]). Finally, novel methods of sample analysis are especially important in the field of current applied microbiology. This was reflected by appearance of several articles in the journal, which were devoted to studies based on various biosensors and can be exemplified by electric bio-chips [68].

Apart from original reports, mentioned above, a group of review articles was published, in which current problems of molecular biology and genetics were discussed in the light of the microbial cell factory concept. Some of them touched the concept directly [69-71], while other were 
devoted to discuss cell factories in the light of stress responses $[72,73]$, protein modification and quality control $[4,6]$, regulation of gene expression $[74,75]$, metagenomics [76], development and production of recombinant vaccines [77], and modern biosensors and analytical methods $[53,78]$.

On the other hand, a large number of relevant reports have dealt with to the use of microorganisms for the production of natural molecules. Various reviews were devoted to microbial polysaccharides, whose importance in biotechnology is rapidly increasing: among these, one excellent paper by Ruffing and Chen [79] reported on numerous efforts made to enhance oligo- and poly-saccharide production in different microorganisms. Various articles were also devoted to the synthesis of amino acids of relevant industrial interest: over-production of phenylalanine, glutamate and most recently lysine [47] was studied in engineered E. coli strains and in Corynebacterium glutamicum. Various authors reported on the over-production of molecules of interest for food and human health by organisms such as Escherichia and Proteus and most recently Marx et al. [65] reported on the accumulation of riboflavin by a genetically engineered strain of Pichia pastoris. A very interesting review of works focusing on the use of various yeasts as cell factories for the production of fine chemicals and active pharmaceutical ingredients was published very recently by Pscheidt and Glieder [80]. Saccharomyces cerevisiae was also used by Branduardi et al [34] to study lactate production. In 2005, a review by Dutta et al [81] focused on hydrogen production by cyanobacteria, another field of high biotechnological interest in these times of energy shortage. Finally a new very stable bacteriocin of particular interest as an antimicrobial agent for solid foods and for industrial operation at high temperature was described by Martirani et al [12].

During these years Microbial Cell Factories has given a significant contribution also to the description of new or improved microbial strains for biotechnological applications. Sivaprakasan et al [82] reported on the use of a consortium of salt-tolerant microorganism for saline wastewater treatment. Among others, relevant impact had the construction of engineered strains of Streptomyces pilosus [61], Lactococcus lactis [64] and Escherichia coli $[28,57,67]$ for the control of gene expression aimed at enhancing industrial productions. Optimization of industrial media for yeast and Bacillus was reported by HahnHagerdal et al [50] and Zweers et al [14], respectively.

Regarding food microbiology, the journal has published research articles on food-related microbes' metabolism and physiology issues of industrial importance. In this context, a poorly characterized pathway for sucrose utilization in Saccharomyces cerevisiae was engineered to improve biomass-directed applications of the organism, in the work of Badotti et al [29]. Modulation at the molecular level of the rate of active sucrose uptake resulted in yeast strains that can easily attain higher cell densities with elevated sucrose levels avoiding overflow metabolism. The regulatory features of the pathways involved in methanol utilization by yeasts have been extensively reviewed by Hartner and Glieder [83]. The applications of methylotrophic yeasts are expanding today, beyond the established for single cell protein and recombinant protein production, to the biopharmaceuticals area and the production of therapeutic antibodies. The key role of thioredoxin reductase in the oxidative stress response of Lactobacillus plantarum was reported by Serrano et al [84]. The authors proposed that overproduction of the trxB1encoded TR in Lactobacillus plantarum improves tolerance towards oxidative stress. This latter property can be used for engineering robustness towards oxidative stress in industrial strains of $L$. plantarum. Also, the adaptation to heat shock in L. plantarum was studied [85].

On the other hand, the identification or microbial metabolites produced during the food fermentation or during bioprocesses can be highly important regarding food additives or potential nutraceuticals. A genomic search approach that combined methods based on automatic and manual searches of homology and motifs among Propionibacterium freudenreichii was presented [59] as a tool for the prediction-identification of esterases, the lypolytic enzymes involved in Emmental cheese maturation and flavour development. Vanillin production and optimization using metabolically engineered $E$. coli have been also reported [86]. Ferulic acid was efficiently converted to vanillin in the reported work, without accumulation of undesirable vanillin reduction/oxidation products, using E. coli JM109 cells expressing genes from the ferulic aciddegrader Pseudomonas fluorescens BF13. Selection for spontaneous roseoflavin-resistant mutants was found to be a reliable method to obtain natural riboflavin-overproducing strains of a number of species (Lactobacillus $(L b$.) plantarum, Leuconostoc (Lc.) mesenteroides and Propionibacterium (P.) freudenreichii) commonly used in the food industry [87]. The use of such starter strains can be exploited to increase the vitamin content in certain food products. Microbial exopolysaccharides make an important class of food components. They are produced by dairy (Lactococcus and Streptococcus spp.) and non-dairy bacteria, and in-situ synthesis allows modulation of rheology, improved mouthfeel, and texture of food products while it imparts some health benefits as prebiotics. Metabolic engineering strategies and various production aspects have been extensively reviewed [79]. Other classes of natural products that are increasingly becoming the centre of attention of the pharmaceutical and nutraceutical industries are isoprenoids, flavonoids and long chain polyun- 
saturated fatty acids. The use of $S$. cerevisiae as a cell factory for the biosynthesis of these high-value natural products has been also reviewed in Microbial Cell Factories [88].

The microbial production of enzymes used in the food industry has also had a place in the journal. Secretion and properties of a hybrid Kluyveromyces lactis-Aspergillus niger beta-galactosidase has been reported [89], as well as various aspects of the industrial scale production of chymosin by Aspergillus niger [90]. Overproduction of the important for the food industry pectin lyase was achieved by encapsulation of recombinant strains of $E$. coli in alginate or alginate/silica beads [91]. Regarding the exploitation of lactic acid bacteria in the production of valuable biotechnological products, contributions have reported the optimization of the nisin controlled gene expression system NICE of Lactococcus lactis for industrial purposes [64] and the applications of this system, ranging from membrane proteins to large scale processes [92], were also described.

Regarding food safety, a method based on electrochemical detection on a biochip enabling a fast characterization and monitoring of pathogens (microbial cells and spores) in food has been reported [68], as well as the evaluation and comparisons of bioassays and indicator microorganisms used in bacteriocin determination in processed food samples [93].

In summary, Microbial Cell Factories is offering a new open forum for the presentation and discussion of novel tools and scientific concepts regarding the use of microorganims for the production and transformation of biotechnologically relevant substances. The role of the journal, supported by an international, well experienced editorial board will keep being the publication of manuscripts of relevant and general interest in the Cell Factory context but also the cooperation with scientific conferences and the promotion of any way of scientific communication in this and related fields. We highly appreciate the valuable support of the authors, readers, referees, editors and the whole scientific community in these early stages of the journal development and consolidation.

\section{References}

I. García-Fruitós E, González-Montalbán N, Morell M, Vera A, Ferraz RM, Arís A, Ventura S, Villaverde A: Aggregation as bacterial inclusion bodies does not imply inactivation of enzymes and fluorescent proteins. Microb Cell Fact 2005, 4:27.

2. Lethanh H, Neubauer P, Hoffmann F: The small heat-shock proteins IbpA and IbpB reduce the stress load of recombinant Escherichia coli and delay degradation of inclusion bodies. Microb Cell Fact 2005, 4:6.

3. Vallejo LF, Rinas U: Strategies for the recovery of active proteins through refolding of bacterial inclusion body proteins. Microb Cell Fact 2004, 3: II.

4. Miot M, Betton JM: Protein quality control in the bacterial periplasm. Microb Cell Fact 2004, 3:4.

5. Gasser B, Saloheimo M, Rinas U, Dragosits M, Rodríguez-Carmona E, Baumann K, Giuliani M, Parrilli E, Branduardi P, Lang C, Porro D, Ferrer $P$, Tutino ML, Mattanovich D, Villaverde A: Protein folding and conformational stress in microbial cells producing recombinant proteins: a host comparative overview. Microb Cell Fact 2008, 7:II.

6. Weibezahn J, Bukau B, Mogk A: Unscrambling an egg: protein disaggregation by AAA+ proteins. Microb Cell Fact 2004, 3: I.

7. Baneyx F: Keeping up with protein folding. Microb Cell Fact 2004, 3:6.

8. de Marco A: Minimal information: an urgent need to assess the functional reliability of recombinant proteins used in biological experiments. Microb Cell Fact 2008, 7:20.

9. de Marco A: A step ahead: combining protein purification and correct folding selection. Microb Cell Fact 2004, 3: 12.

10. Sorensen HP, Mortensen KK: Soluble expression of recombinant proteins in the cytoplasm of Escherichia coli. Microb Cell Fact 2005, 4: I.

II. Dummler A, Lawrence AM, de MA: Simplified screening for the detection of soluble fusion constructs expressed in $E$. coli using a modular set of vectors. Microb Cell Fact 2005, 4:34.

12. Martirani L, Varcamonti M, Naclerio G, De FM: Purification and partial characterization of bacillocin 490, a novel bacteriocin produced by a thermophilic strain of Bacillus licheniformis. Microb Cell Fact 2002, I:I.

13. Rosso AM, Ferrarotti SA, Krymkiewicz N, Nudel BC: Optimisation of batch culture conditions for cyclodextrin glucanotransferase production from Bacillus circulans DF 9R. Microb Cell Fact 2002, I:3.

14. Zweers JC, Barák I, Becher D, Driessen AJ, Hecker M, Kontinen VP, Saller MJ, Vavrová L, van Dijl JM: Towards the development of Bacillus subtilis as a cell factory for membrane proteins and protein complexes. Microb Cell Fact 2008, 7:10.

I5. Joosten V, Lokman C, Hondel CA Van Den, Punt PJ: The production of antibody fragments and antibody fusion proteins by yeasts and filamentous fungi. Microb Cell Fact 2003, 2: I.

16. Nakashima N, Mitani Y, Tamura T: Actinomycetes as host cells for production of recombinant proteins. Microb Cell Fact 2005, 4:7.

17. Viitanen MI, Vasala A, Neubauer P, Alatossava T: Cheese wheyinduced high-cell-density production of recombinant proteins in Escherichia coli. Microb Cell Fact 2003, 2:2.

18. Mierau I, Leij P, van Swam I, Blommestein B, Floris E, Mond J, Smid EJ: Industrial-scale production and purification of a heterologous protein in Lactococcus lactis using the nisin-controlled gene expression system NICE: the case of lysostaphin. Microb Cell Fact 2005, 4: I5.

19. Le Loir Y, Azevedo V, Oliveira SC, Freitas DA, Miyoshi A, BermúdezHumarán LG, Nouaille S, Ribeiro LA, Leclercq S, Gabriel JE, Guimaraes VD, Oliveira MN, Charlier C, Gautier M, Langella P: Protein secretion in Lactococcus lactis: an efficient way to increase the overall heterologous protein production. Microb Cell Fact 2005, 4:2

20. Blecha A, Zarschler K, Sjollema KA, Veenhuis M, Rodel G: Expression and cytosolic assembly of the $S$-layer fusion protein mSbsC-EGFP in eukaryotic cells. Microb Cell Fact 2005, 4:28.

21. Parrilli E, De VD, Cirulli C, Tutino ML: Development of an improved Pseudoalteromonas haloplanktis TACI 25 strain for recombinant protein secretion at low temperature. Microb Cell Fact 2008, 7:2.

22. Salzano AM, Febbraio F, Farias T, Cetrangolo GP, Nucci R, Scaloni A, Manco G: Redox stress proteins are involved in adaptation response of the hyperthermoacidophilic archaeon Sulfolobus solfataricus to nickel challenge. Microb Cell Fact 2007, 6:25.

23. Ventura S: Sequence determinants of protein aggregation: tools to increase protein solubility. Microb Cell Fact 2005, 4: I I.

24. Ignatova Z: Monitoring protein stability in vivo. Microb Cell Fact 2005, 4:23.

25. Banki MR, Wood DW: Inteins and affinity resin substitutes for protein purification and scale up. Microb Cell Fact 2005, 4:32.

26. Philibert P, Martineau P: Directed evolution of single-chain Fv for cytoplasmic expression using the beta-galactosidase complementation assay results in proteins highly susceptible to protease degradation and aggregation. Microb Cell Fact 2004, 3:16.

27. Scheibel T: Spider silks: recombinant synthesis, assembly, spinning, and engineering of synthetic proteins. Microb Cell Fact 2004, 3:14. 
28. Gosset G: Improvement of Escherichia coli production strains by modification of the phosphoenolpyruvate:sugar phosphotransferase system. Microb Cell Fact 2005, 4: I4.

29. Badotti F, Dário MG, Alves SL Jr, Cordioli ML, Miletti LC, de Araujo PS, Stambuk BU: Switching the mode of sucrose utilization by Saccharomyces cerevisiae. Microb Cell Fact 2008, 7:4.

30. Salusjarvi L, Kankainen M, Soliymani R, Pitkanen JP, Penttila M, Ruohonen $L$ : Regulation of xylose metabolism in recombinant Saccharomyces cerevisiae. Microb Cell Fact 2008, 7:18.

31. Petschacher B, Nidetzky B: Altering the coenzyme preference of xylose reductase to favor utilization of NADH enhances ethanol yield from xylose in a metabolically engineered strain of Saccharomyces cerevisiae. Microb Cell Fact 2008, 7:9.

32. Liang L, Zhang J, Lin Z: Altering coenzyme specificity of Pichia stipitis xylose reductase by the semi-rational approach CASTing. Microb Cell Fact 2007, 6:36.

33. Karhumaa K, Garcia SR, Hahn-Hagerdal B, Gorwa-Grauslund MF: Comparison of the xylose reductase-xylitol dehydrogenase and the xylose isomerase pathways for xylose fermentation by recombinant Saccharomyces cerevisiae. Microb Cell Fact 2007, 6:5.

34. Branduardi P, Sauer M, De Gioia L, Zampella G, Valli M, Mattanovich $D$, Porro $D$ : Lactate production yield from engineered yeasts is dependent from the host background, the lactate dehydrogenase source and the lactate export. Microb Cell Fact 2006, 5:4.

35. Martínez K, de Anda R, Hernández G, Escalante A, Gosset G, Ramírez OT, Bolívar FG: Coutilization of glucose and glycerol enhances the production of aromatic compounds in an Escherichia coli strain lacking the phosphoenolpyruvate: carbohydrate phosphotransferase system. Microb Cell Fact 2008, 7:I

36. Cardillo AB, Rodriguez TJ, Giulietti AM: Expression of Brugmansia candida Hyoscyamine 6beta-Hydroxylase gene in Saccharomyces cerevisiae and its potential use as biocatalyst. Microb Cell Fact 2008, 7:I7.

37. Martin JF, Gudina E, Barredo JL: Conversion of beta-carotene into astaxanthin: Two separate enzymes or a bifunctional hydroxylase-ketolase protein? Microb Cell Fact 2008, 7:3.

38. Galindo E, Pena C, Nunez C, Segura D, Espin G: Molecular and bioengineering strategies to improve alginate and polydydroxyalkanoate production by Azotobacter vinelandii. Microb Cell Fact 2007, 6:7.

39. Mattanovich D, Borth N: Applications of cell sorting in biotechnology. Microb Cell Fact 2006, 5:12.

40. Sauer M, Branduardi P, Gasser B, Valli M, Maurer M, Porro D, Mattanovich $D$ : Differential gene expression in recombinant Pichia pastoris analysed by heterologous DNA microarray hybridisation. Microb Cell Fact 2004, 3: 17.

4I. Baez-Viveros JL, Flores N, Juarez K, Castillo-Espana P, Bolivar F, Gosset G: Metabolic transcription analysis of engineered Escherichia coli strains that overproduce L-phenylalanine. Microb Cell Fact 2007, 6:30.

42. Peano C, Bicciato S, Corti G, Ferrari F, Rizzi E, Bonnal RJ, Bordoni R, Albertini A, Bernardi LR, Donadio S, De Bellis G: Complete gene expression profiling of Saccharopolyspora erythraea using GeneChip DNA microarrays. Microb Cell Fact 2007, 6:37.

43. Jaluria $\mathrm{P}$, Konstantopoulos K, Betenbaugh M, Shiloach J: A perspective on microarrays: current applications, pitfalls, and potential uses. Microb Cell Fact 2007, 6:4.

44. Graham RL, Graham C, McMullan G: Microbial proteomics: a mass spectrometry primer for biologists. Microb Cell Fact 2007, 6:26.

45. Wittmann C: Fluxome analysis using GC-MS. Microb Cell Fact 2007, 6:6.

46. Frick $O$, Wittmann C: Characterization of the metabolic shift between oxidative and fermentative growth in Saccharomyces cerevisiae by comparative I3C flux analysis. Microb Cell Fact 2005, 4:30.

47. Becker J, Klopprogge C, Wittmann C: Metabolic responses to pyruvate kinase deletion in lysine producing Corynebacterium glutamicum. Microb Cell Fact 2008, 7:8.

48. Faijes $M$, Mars $A E$, Smid EJ: Comparison of quenching and extraction methodologies for metabolome analysis of Lactobacillus plantarum. Microb Cell Fact 2007, 6:27.
49. Ferrer P: Systems biology and biological systems diversity for the engineering of microbial cell factories. Microb Cell Fact 2007, 6:35.

50. Hahn-Hagerdal B, Karhumaa K, Larsson CU, Gorwa-Grauslund M, Gorgens J, van Zyl WH: Role of cultivation media in the development of yeast strains for large scale industrial use. Microb Cell Fact 2005, 4:31.

5I. Cos O, Ramon R, Montesinos JL, Valero F: Operational strategies, monitoring and control of heterologous protein production in the methylotrophic yeast Pichia pastoris under different promoters: a review. Microb Cell Fact 2006, 5: 17

52. Patnaik PR: "Intelligent" descriptions of microbial kinetics in finitely dispersed bioreactors: neural and cybernetic models for PHB biosynthesis by Ralstonia eutropha. Microb Cell Fact 2007, 6:23.

53. Clementschitsch F, Bayer K: Improvement of bioprocess monitoring: development of novel concepts. Microb Cell Fact 2006, 5:19.

54. Betts Jl, Baganz F: Miniature bioreactors: current practices and future opportunities. Microb Cell Fact 2006, 5:21.

55. Rautio J, Barken KB, Lahdenpera J, Breitenstein A, Molin S, Neubauer $P$ : Sandwich hybridisation assay for quantitative detection of yeast RNAs in crude cell lysates. Microb Cell Fact 2003, 2:4.

56. Skulj M, Okrslar V, Jalen S, Jevsevar S, Slanc P, Strukelj B, Menart V: Improved determination of plasmid copy number using quantitative real-time PCR for monitoring fermentation processes. Microb Cell Fact 2008, 7:6.

57. Heermann R, Zeppenfeld T, Jung K: Simple generation of sitedirected point mutations in the Escherichia coli chromosome using Red/ET Recombination. Microb Cell Fact 2008, 7: I4.

58. Büssow K, Scheich C, Sievert V, Harttig U, Schultz J, Simon B, Bork P, Lehrach H, Heinemann U: Structural genomics of human proteins - target selection and generation of a public catalogue of expression clones. Microb Cell Fact 2005, 4:21.

59. Dherbecourt J, Falentin H, Canaan S, Thierry A: A genomic search approach to identify esterases in Propionibacterium freudenreichii involved in the formation of flavour in Emmental cheese. Microb Cell Fact 2008, 7:16.

60. Wang Z, Xiang L, Shao J, Wegrzyn A, Wegrzyn G: Effects of the presence of ColEI plasmid DNA in Escherichia coli on the host cell metabolism. Microb Cell Fact 2006, 5:34.

6I. Flores FJ, Rincon J, Martin JF: Characterization of the iron-regulated desA promoter of Streptomyces pilosus as a system for controlled gene expression in actinomycetes. Microb Cell Fact 2003, 2:5.

62. Vethanayagam JG, Flower AM: Decreased gene expression from T7 promoters may be due to impaired production of active T7 RNA polymerase. Microb Cell Fact 2005, 4:3.

63. Soini J, Falschlehner C, Mayer C, Böhm D, Weinel S, Panula J, Vasala A, Neubauer P: Transient increase of ATP as a response to temperature up-shift in Escherichia coli. Microb Cell Fact 2005, 4:9.

64. Mierau I, Olieman K, Mond J, Smid EJ: Optimization of the Lactococcus lactis nisin-controlled gene expression system NICE for industrial applications. Microb Cell Fact 2005, 4: I6.

65. Marx H, Mattanovich D, Sauer M: Overexpression of the riboflavin biosynthetic pathway in Pichia pastoris. Microb Cell Fact 2008, 7:23.

66. Bahey-El-Din M, Griffin BT, Gahan CG: Nisin inducible production of listeriolysin $\mathbf{O}$ in Lactococcus lactis NZ9000. Microb Cell Fact 2008, 7:24.

67. Roge J, Betton JM: Use of pIVEX plasmids for protein overproduction in Escherichia coli. Microb Cell Fact 2005, 4: 18.

68. Gabig-Ciminska M, Andresen H, Albers J, Hintsche R, Enfors SO Identification of pathogenic microbial cells and spores by electrochemical detection on a biochip. Microb Cell Fact 2004, 3:2.

69. Danchin A: The bag or the spindle: the cell factory at the time of systems' biology. Microb Cell Fact 2004, 3: I3.

70. Bansal AK: Bioinformatics in microbial biotechnology - a mini review. Microb Cell Fact 2005, 4:19.

7I. Centeno NB, Planas-Iglesias J, Oliva B: Comparative modelling of protein structure and its impact on microbial cell factories. Microb Cell Fact 2005, 4:20.

72. Wegrzyn G, Wegrzyn A: Stress responses and replication of plasmids in bacterial cells. Microb Cell Fact 2002, I:2. 
73. DeLisa MP, Bentley WE: Bacterial autoinduction: looking outside the cell for new metabolic engineering targets. Microb Cell Fact 2002, I:5.

74. Lioliou EE, Kyriakidis DA: The role of bacterial antizyme: From an inhibitory protein to AtoC transcriptional regulator. Microb Cell Fact 2004, 3:8.

75. Skorupska A, Janczarek M, Marczak M, Mazur A, Krol J: Rhizobial exopolysaccharides: genetic control and symbiotic functions. Microb Cell Fact 2006, 5:7.

76. Yun J, Ryu S: Screening for novel enzymes from metagenome and SIGEX, as a way to improve it. Microb Cell Fact 2005, 4:8.

77. Glenting J, Wessels S: Ensuring safety of DNA vaccines. Microb Cell Fact 2005, 4:26.

78. Gabig-Ciminska M: Developing nucleic acid-based electrical detection systems. Microb Cell Fact 2006, 5:9.

79. Ruffing A, Chen RR: Metabolic engineering of microbes for oligosaccharide and polysaccharide synthesis. Microb Cell Fact 2006, 5:25.

80. Pscheidt B, Glieder A: Yeast cell factories for fine chemical and API production. Microb Cell Fact 2008, 7:25.

81. Dutta D, De D, Chaudhuri S, Bhattacharya SK: Hydrogen production by Cyanobacteria. Microb Cell Fact 2005, 4:36.

82. Sivaprakasam S, Mahadevan S, Sekar S, Rajakumar S: Biological treatment of tannery wastewater by using salt-tolerant bacterial strains. Microb Cell Fact 2008, 7:15.

83. Hartner FS, Glieder A: Regulation of methanol utilisation pathway genes in yeasts. Microb Cell Fact 2006, 5:39.

84. Serrano LM, Molenaar D, Wels M, Teusink B, Bron PA, de Vos WM, Smid E): Thioredoxin reductase is a key factor in the oxidative stress response of Lactobacillus plantarum WCFSI. Microb Cell Fact 2007, 6:29.

85. Castaldo C, Siciliano RA, Muscariello L, Marasco R, Sacco M: CcpA affects expression of the groESL and dnaK operons in Lactobacillus plantarum. Microb Cell Fact 2006, 5:35.

86. Barghini P, Di GD, Fava F, Ruzzi M: Vanillin production using metabolically engineered Escherichia coli under non-growing conditions. Microb Cell Fact 2007, 6: 13.

87. Burgess CM, Smid EJ, Rutten G, van SD: A general method for selection of riboflavin-overproducing food grade microorganisms. Microb Cell Fact 2006, 5:24.

88. Chemler JA, Yan Y, Koffas MA: Biosynthesis of isoprenoids, polyunsaturated fatty acids and flavonoids in Saccharomyces cerevisiae. Microb Cell Fact 2006, 5:20.

89. Rodriguez AP, Leiro RF, Trillo MC, Cerdan ME, Siso MI, Becerra M: Secretion and properties of a hybrid Kluyveromyces lactisAspergillus niger beta-galactosidase. Microb Cell Fact 2006, 5:41.

90. Hellmuth K: Industrial scale production of chymosin with Aspergillus niger. Microb Cell Fact 2006, 5(SuppI I):S3I.

91. Papi RM, Chaitidou SA, Trikka FA, Kyriakidis DA: Encapsulated Escherichia coli in alginate beads capable of secreting a heterologous pectin lyase. Microb Cell Fact 2005, 4:35.

92. Mierau I: Nlisin Controlled gene Expression (NICE) in Lactococcus lactis - versatile applications ranging from membrane proteins to large scale processes. Microb Cell Fact 2006:S39.

93. Papagianni M, Avramidis N, Filioussis G, Dasiou D, Ambrosiadis I: Determination of bacteriocin activity with bioassays carried out on solid and liquid substrates: assessing the factor "indicator microorganism". Microb Cell Fact 2006, 5:30.

\section{Competing interests}

The authors declare no competing interests.
Publish with Biomed Central and every scientist can read your work free of charge

"BioMed Central will be the most significant development for disseminating the results of biomedical research in our lifetime. "

Sir Paul Nurse, Cancer Research UK

Your research papers will be:

- available free of charge to the entire biomedical community

- peer reviewed and published immediately upon acceptance

- cited in PubMed and archived on PubMed Central

- yours - you keep the copyright
BioMedcentral 